\title{
The absorption of iron, with or without supplements of single amino acids and of ascorbic acid, in healthy and Fe-deficient children
}

\author{
By M. F. S. EL-HAWARY, F. A. EL-SHOBAKI AND T. KHOLEIF \\ National Research Centre, Dokki, Cairo, Egypt \\ AND R. SAKR \\ Faculty of Medicine, Cairo University, Cairo, Egypt \\ AND M. EL-BASSOUSSY \\ Faculty of Medicine, Mansoura University, El Mansoura, Egypt
}

(Received I8 March I974 - Accepted 30 October 1974)

\begin{abstract}
I. Studies were done on the effect of ascorbic acid and five amino acids (histidine, cystine, cysteine, valine and glutamic acid) on intestinal iron absorption in a group of ninety Egyptian infants and young children, of which fifty-seven were healthy controls and thirty-three were suffering from $\mathrm{Fe}$-deficiency anaemia.

2. Supplements tested promoted Fe absorption in healthy controls in the following order: valine $>$ histidine $>$ ascorbic acid. Cysteine, glutamic acid and cystine were found to have no significant effect.

3. Supplementation with valine, ascorbic acid and histidine also increased intestinal $\mathrm{Fe}$ absorption in anaemic subjects, but to a lesser extent than in controls.

4. Supplementation of haematinic therapy with these compounds is recommended. Their use is also suggested to improve the availability of the Fe content of everyday diets.
\end{abstract}

The protein content of the diet is believed to affect intestinal iron absorption (Conrad, Foy, Williams \& Knospe, I967). By changing the diet of animals from lowto high-protein, Higginson, Grady \& Huntly (1965) found an increase in the absorption of radioactive $\mathrm{Fe}$ from the gut. This promoting action on $\mathrm{Fe}$ absorption may be partly the result of the action of free amino acids released from dietary proteins. The effect of amino acids on the process of $\mathrm{Fe}$ absorption in the intestine was studied in animals by several workers (Kinney, Kaufman \& Klavins, 1962; Van Campen \& Gross, 1969). Martinez-Torres \& Layrisse (1970) found that absorption of Fe from black beans was doubled when they were fed together with either fish or with an amino acid mixture similar quantitatively and qualitatively with that present in $100 \mathrm{~g}$ fish.

Although there is an adequate supply of $\mathrm{Fe}$ in the diet of Egyptians, anaemia of various aetiologies is frequent, especially during infancy and childhood (El-Shobaki, 1970).

Better absorption and, therefore, utilization of dietary Fe might result from supplementation with compounds that could promote these effects. In the following study we have evaluated the effects of ascorbic acid, and some amino acids (histidine, cystine, cysteine, valine and glutamic acid) on Fe absorption in the intestine. 


\section{MATERIALS AND METHODS}

Ninety subjects were studied of which fifty-seven were healthy subjects with an age range of 8 months-12.5 years and thirty-three had Fe-deficiency anaemia and were of an age range of $2 \cdot 5-9 \cdot 5$ years.

The healthy subjects were relatives of the anaemic subjects, and all were hospitalized in the Mounira Children's Hospital, Faculty of Medicine, Cairo University, and El-Mansoura Hospital, Faculty of Medicine, Mansoura University. They were clinically examined and those showing any complications that might interfere with the results were excluded from the study. During their stay in the hospital, the children received the hospital diet containing an adequate supply of nutrients.

An early morning, fasting blood sample $(5 \mathrm{ml})$ was taken using an all-glass, sterile syringe and transferred into two tubes: $\mathrm{x} \mathrm{ml}$ to a tube containing potassium oxalate ( $\mathrm{ml}$ of a $\mathrm{IO} \mathrm{g} / \mathrm{l}$ solution, evaporated to dryness) for determination of the haemoglobin and packed cell volume, and the remaining $4 \mathrm{ml}$ was retained for separation of the serum to determine serum Fe and total Fe-binding capacity. An oral dose of $4 \mathrm{mg} \mathrm{Fe}$ (as ferrous sulphate) $/ \mathrm{kg}$ body-weight was given to each individual either alone or together with a supplement $(500 \mathrm{mg}$ ascorbic acid or $\mathrm{I}$ mmol of each of the amino acids: histidine, cystine, valine, cysteine and glutamic acid). Amino acids used were 'extra pure' L-isomers obtained from BDH Chemicals Ltd, Poole, Dorset, and E. Merck AG, Darmstadt, West Germany. A further blood sample was taken $4 \mathrm{~h}$ after administration of the dose, i.e. the time previously found to correspond to maximum absorption (El-Shobaki, El-Hawary, Morcos, Abdel-Khalek, El-Zawahry \& Sakr, 1972).

The effect of each supplement was tested using groups of individuals. For the fiftyseven controls the treatments were: seventeen ferrous sulphate, seven ascorbic acid, five histidine, six cystine, seven valine, seven cysteine and eight glutamic acid. For the thirty-three anaemic subjects the treatments were: nine ferric sulphate alone, and five, seven, six and six received the same Fe dose plus ascorbic acid, cystine, histidine or valine respectively, in the same amounts as the corresponding controls.

Haemoglobin was determined by the method of Wong (r928), and serum $\mathrm{Fe}$ and total Fe-binding capacity were estimated by the methods described by Ramsay $(\mathrm{I} 957 a, b)$.

\section{RESULTS}

As shown in Table I, values for haemoglobin and packed cell volume for healthy Egyptian children ranged from 96 to $144 \mathrm{~g} / \mathrm{l}$ (mean and SE $\mathrm{II} \mathrm{I}^{\cdot} \cdot 4 \pm \mathrm{I} \cdot 7$ ) and 0.30 to 0.42 $(0.33 \pm 0.003)$ respectively. For anaemic children, the values for haemoglobin ranged from 47 to $102 \mathrm{~g} / 1$ (mean $76 \pm 2$ ) and for packed cell volume ranged from $0 \cdot 18$ to 0.30 (mean $0.24 \pm 0.005)$. Serum Fe levels $(\mu \mathrm{mol} / 1)$ of healthy subjects ranged from 9.85 to 20.8 (mean $15.4 \pm 0.4 \mathrm{I}$ ) as compared with $5.37^{-10.0}$ (mean $8.2 \pm 0.2 \mathrm{I}$ ) for anaemic subjects. The total Fe-binding capacity $(\mu \mathrm{mol} / 1)$ of controls ranged from $22 \cdot 9$ to $58 \cdot 6$ (mean $36 \cdot 0 \pm 0.88$ ) with a percentage saturation of transferrin of $30 \pm 0.73$. For anaemic 
Table I. Haemogolobin level, packed cell volume, serum iron level, total and unsaturated Fe-binding capacity and saturation of transferrin for healthy and Fe-deficient anaemic Egyptian children

(Mean values with their standard errors; ranges in parentheses)

\begin{tabular}{|c|c|c|c|c|c|c|}
\hline & \multirow{2}{*}{$\begin{array}{l}\text { Haemo- } \\
\text { globin } \\
(\mathrm{g} / \mathrm{l})\end{array}$} & \multirow[b]{2}{*}{$\begin{array}{l}\text { Packed cell } \\
\text { volume }\end{array}$} & \multirow{2}{*}{$\underset{(\mu \mathrm{mol} / \mathrm{l})}{\operatorname{Serum} \mathrm{Fe}}$} & \multicolumn{2}{|c|}{$\begin{array}{l}\text { Fe-binding capacity } \\
(\mu \mathrm{mol} / 1)\end{array}$} & \multirow{2}{*}{$\begin{array}{c}\text { Saturation } \\
\text { of transferrin } \\
(\%)\end{array}$} \\
\hline & & & & Total & Unsaturated & \\
\hline & Mean & Mean & Mean & Mean & Mean & Mean \\
\hline Control & $\begin{array}{l}\operatorname{III} 4 \quad x \cdot 7 \\
\quad(96-I 44)\end{array}$ & $\begin{array}{cc}0.33 & 0.003 \\
(0.30-0.42)\end{array}$ & $\begin{array}{l}15.4 \quad 0.4 I \\
(9.85-20.8)\end{array}$ & $\begin{array}{ll}51 \cdot 2 & 1 \cdot 0 \\
(36 \cdot 0-64 \cdot 4)\end{array}$ & $\begin{array}{lr}36 \cdot 0 \quad 0.88 \\
(22 \cdot 9-58 \cdot 6)\end{array}$ & $\begin{array}{c}30 \cdot 0 \quad 0 \cdot 73 \\
(2 x-40)\end{array}$ \\
\hline Anaemic & $\begin{array}{c}76 \cdot 0 \quad 2 \cdot 1 \\
(47-102)\end{array}$ & $\begin{array}{c}0.240 .005 \\
(0.18-0.30)\end{array}$ & $\begin{array}{cc}8 \cdot 2 & 0.21 \\
(5 \cdot 37-10.0)\end{array}$ & $\begin{array}{cc}62 \cdot 8 & 0 \cdot 34 \\
\left(53^{\circ} 7-77 \cdot 3\right)\end{array}$ & $\begin{array}{l}54^{\cdot 6} \quad \text { I.2 } \\
\left(43^{\circ} 7-70^{\circ} 2\right)\end{array}$ & $\begin{array}{c}13 \cdot 20.46 \\
(7 \cdot 6-18 \cdot 7)\end{array}$ \\
\hline
\end{tabular}

Table 2. The level of serum iron $(\mu \mathrm{mol} / \mathrm{l})_{4} \mathrm{~h}$ after an oral dose of $4 \mathrm{mg} \mathrm{Fe}$ (as ferrous sulphate)/kg body-weight in the presence or absence of ascorbic acid or amino acid supplements, and ${ }_{4} h$ serum $F e$ :fasting serum $F e$ in healthy and $F e$-deficient anaemic Egyptian children

(Mean values with their standard errors; ranges in parentheses)

\begin{tabular}{|c|c|c|c|c|}
\hline \multirow[b]{3}{*}{ Supplement } & \multicolumn{2}{|c|}{ Control } & \multicolumn{2}{|c|}{ Anaemic } \\
\hline & $4 h$ & $4 \mathrm{~h}:$ fasting & $4 h$ & $4 \mathrm{~h}$ : fasting \\
\hline & Mean & Mean & Mean & Mean \\
\hline None & $\begin{array}{c}34 \cdot 5 \quad 0 \cdot 63 \\
(22 \cdot 9-46 \cdot 5)\end{array}$ & $\begin{array}{c}2 \cdot 14 \quad 0 \cdot 11 \\
(1 \cdot 64-3 \cdot 2)\end{array}$ & $\begin{array}{cc}4 x \cdot 0 & 2 \cdot I \\
(3 I \cdot 5-50 \cdot I)\end{array}$ & $\begin{array}{c}4.5 \quad 0.23 \\
(3.6-5 \cdot 5)\end{array}$ \\
\hline Valine (I $\mu \mathrm{mol}$ ) & $\begin{array}{cc}45 \cdot 6 & 0.89 \\
(37 \cdot 2-59 \cdot 6)\end{array}$ & $\begin{array}{c}3 \cdot 33 \quad 0.37 \\
(2 \cdot 26-4 \cdot 76)\end{array}$ & $\begin{array}{cc}48 \cdot 7 & 4 \cdot 1 \\
(36 \cdot 7-63 \cdot 4)\end{array}$ & 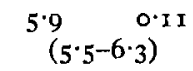 \\
\hline Ascorbic acid (500 mg) & $\begin{array}{rr}44 \cdot 8 & 2 \cdot 6 \\
(32 \cdot 9-51 \cdot 6)\end{array}$ & $\begin{array}{cc}3.01 & 0.19 \\
(2.27-3.60)\end{array}$ & $\begin{array}{lr}42 \cdot 8 & 2 \cdot 5 \\
(38 \cdot 5-50 \cdot I)\end{array}$ & $\begin{array}{c}5.7 \\
(5 \cdot 4-6 \cdot 1)\end{array}$ \\
\hline Histidine (x $\mu \mathrm{mol}$ ) & $\begin{array}{cc}4 I \cdot 3 & 3 \cdot 3 r \\
(33 \cdot 3-48 \cdot 3)\end{array}$ & $\begin{array}{cc}3.04 & 0.43 \\
(2 \cdot 40-4 \cdot 28)\end{array}$ & $\begin{array}{lr}38 \cdot 1 & 2 \cdot 5 \\
(33 \cdot 1-46 \cdot 5)\end{array}$ & $\begin{array}{l}5 \cdot 1 \quad 0.28 \\
(4 \cdot 2-5 \cdot 8)\end{array}$ \\
\hline Cystine (r $\mu \mathrm{mol}$ ) & $\begin{array}{rr}30 \cdot 3 & 3 \cdot 4 \\
(22 \cdot 9-46 \cdot 5)\end{array}$ & $\begin{array}{cc}2 \cdot 0 & 0.07 \\
(I \cdot 82-2 \cdot 32)\end{array}$ & $\begin{array}{cr}33 \cdot 6 & 2 \cdot 9 \\
(26 \cdot 0-48 \cdot 3)\end{array}$ & $\begin{array}{cc}4 \cdot 4 & 0.46 \\
(2 \cdot 9-6 \cdot 0)\end{array}$ \\
\hline Cysteine ( $1 \mu \mathrm{mol}$ ) & $\begin{array}{rr}36 \cdot 9 & 2 \cdot 4 \\
(31 \cdot 3-50 \cdot r)\end{array}$ & $\begin{array}{c}2.34 \\
(1.87-2.94)\end{array}$ & - & - \\
\hline Glutamic acid (1 $\mu \mathrm{mol}$ ) & $\begin{array}{cc}31 \cdot 9 & 0 \cdot 75 \\
(28 \cdot 6-34 \cdot 4)\end{array}$ & $\begin{array}{cc}2 \cdot 26 & 0 \cdot 14 \\
(I \cdot 77-2 \cdot 82)\end{array}$ & 一 & - \\
\hline
\end{tabular}

cases, values for total Fe-binding capacity had increased to $53 \cdot 7-77 \cdot 3(\mu \mathrm{mol} / \mathrm{l})$ (mean $62 \cdot 8 \pm 0 \cdot 34)$ and the percentage saturation of transferrin was $13 \cdot 2 \pm 0.46$.

There was an increase in serum Fe levels $4 \mathrm{~h}$ after administration of ferrous sulphate, which was greater in the anaemic children (Table 2). The rate of Fe absorption was also increased in the presence of ascorbic acid, histidine and valine supplements in the order valine $>$ ascorbic acid $>$ histidine. Cystine, cysteine and glutamic acid had no significant effect. The level of serum $\mathrm{Fe} 4 \mathrm{~h}$ after the dose and the $4 \mathrm{~h}$ :fasting serum $\mathrm{Fe}$ ratio for the different treatments in both groups are shown in Table 2. 


\section{DISCUSSION}

A promoting action of amino acids on $\mathrm{Fe}$ absorption has been studied in animals by many workers (Kroe, Kinney, Kaufman \& Klavins, I963; Miller, 1972). Callender (I97I) suggested that results obtained in animals should not be extrapolated too readily to man. Similar studies in man, especially in infants and young children, are of great value.

Mean haemoglobin level (III.4 $\pm \mathrm{I} \cdot 7 \mathrm{~g} / \mathrm{l})$ and packed cell volume $(0.33 \pm 0.0033)$ for our control subjects were similar to those reported by El-Nabawy, Gabr \& Ragab (I96I) and El-Shobaki et al. (1972) but our serum Fe values (15.4 $\pm 0.4 \mathrm{I} \mu \mathrm{mol} / \mathrm{l})$ were lower. The total $(5 \mathrm{I} \cdot 2 \pm \mathrm{I} \cdot 0 \mu \mathrm{mol} / \mathrm{l})$ and unsaturated $(36 \cdot 0 \pm 0 \cdot 88 \mu \mathrm{mol} / \mathrm{l}) \mathrm{Fe}-b i n d i n g$ capacities and percentage saturation of transferrin were similar to those reported by El-Hawary, Sakr, Abdel-Khalek, Ibrahim \& Abdin (1970).

For anaemic subjects, the values for haemoglobin and packed cell volume were found to be about $70 \%$ of those for healthy control subjects; the serum Fe level was $49.1 \%$ of the control value. The total $\mathrm{Fe}$-binding capacity was higher than that of the controls. This, together with the low percentage saturation of transferrin, may be an adaptive mechanism of the body to absorb Fe when it is greatly needed, as indicated by the marked increase in the serum Fe as a result of increased absorption after the oral dose.

The significant increase in Fe absorption (Table 2) after the administration of ascorbic acid may have been due to the formation of a soluble Fe-chelate (Charley, Sarker, Stitt \& Saltman, 1963; Pollack, Kaufman \& Crosby, 1964), and possibly also to the reducing action of ascorbic acid (Brise \& Hallberg, I962).

Supplementation of the $\mathrm{Fe}$ dose with $\mathrm{I} \mu \mathrm{mol}$ histidine in healthy subjects produced a similar effect to that of ascorbic acid; the value for $4 \mathrm{~h}$ :fasting serum Fe levels was 3.04 compared with a value of 3.01 for healthy subjects given Fe plus ascorbic acid. Van Campen (1972) suggested that histidine binds ferrous Fe strongly, forming a stable ring complex which seems to be necessary to maintain it in a soluble and permeable form. He found that ascorbic acid not only improves $\mathrm{Fe}$ absorption when added alone to the solution administered to the subjects, but also when added to the diet; histidine is effective only when added to the Fe solution.

Valine had the greatest promoting effect on $\mathrm{Fe}$ absorption of all the compounds used; the value for $4 \mathrm{~h}$ : fasting serum Fe levels was $3 \cdot 3$ compared with a value of $2 \cdot 14$ for $\mathrm{Fe}$ given alone. This may have been due to the important role of valine in $\mathrm{Fe}$ metabolism. Valine is the $\mathrm{N}$-terminal amino acid in the molecule of transferrin (Stark \& Smyth, 1963).

It is concluded that dietary supplementation with one of the compounds that proved to promote intestinal $\mathrm{Fe}$ absorption, along with haematinics, would be of great value in the treatment of the Fe-deficiency anaemic state. Also supplementation may improve the absorption and utilization of $\mathrm{Fe}$ when $\mathrm{Fe}$ is present at the minimum recommended level in the diet of the general population. 


\section{REFERENCES}

Brise, H. \& Hallberg, L. (ז 962). Acta med. scand. Suppl. 376, 39.

Callender, S. T. (1971). Geront. clin. 13, 44.

Charley, P. J., Sarker, B., Stitt, C. F. \& Saltman, P. (1963). Biochim. biophys. Acta 69, 313.

Conrad, M. E., Foy, A. L., Williams, H. L. \& Knospe, W. H. (1967). Am. F. Physiol. 213, 557.

El-Hawary, M. F. S., Sakr, R., Abdel-Khalek, M. K., Ibrahim, A. M. \& Abdin, M. A. (I970). Gaz. Egypt. paediat. Ass. r8, 29 r.

El-Nabawy, M., Gabr, M. \& Ragab, M. M. (196r). F. trop. Med. Hyg. 64, 271.

El-Shobaki, F. A. (1970). Studies on iron utilization in vivo and in vitro. $\mathrm{PhD}$ Thesis, University of Cairo.

El-Shobaki, F. A., El-Hawary, M. F. S., Morcos, S. R., Abdel-Khalek, M., El-Zawahry, K. \& Sakr, R. (r972). Br. F. Nutr. 28, 8r.

Higginson, J., Grady, M. \& Huntly, C. (1965). F. Lab. Invest. 12, 1260.

Kinney, T. D., Kaufman, N. \& Klavins, J. V. (1962). Nature, Lond. 195, 604.

Kroe, D., Kinney, T. D., Kaufman, N. \& Klavins, J. V. (1963). Blood 21, 546.

Martinez-Torres, C. \& Layrisse, M. (I 970). Blood 35, 669.

Miller, J. (1972). Nutr. Rep. int. 5, 333.

Pollack, S., Kaufman, R. M. \& Crosby, W. H. (r964). Blood 24, 577.

Ramsay, W. N. M. (r957a). Clinica chim. Acta 2, 2 I4.

Ramsay, W. N. M. (I957b). Clinica chim. Acta 2, 214.

Stark, G. R. \& Smyth, D. G. (1963). F. biol. Chem. 238, 214.

Van Campen, D. (1972). F. Nutr. 102, 165.

Van Campen, D. \& Gross, E. (1969). F. Nutr. 99, 68.

Wong, S. Y. (1928). F. biol. Chem. 77, 409. 